УДК 330.101

DOI: $10.25140 / 2411-5215-2020-3(23)-149-157$

\author{
Дмитро Пілевич
}

\title{
ТРАНСФОРМАЦІЯ СИСТЕМИ БУХГАЛТЕРСЬКОГО ОБЛІКУ В УМОВАХ РОЗВИТКУ ЦИФРОВИХ ТЕХНОЛОГІЙ
}

\author{
Дмитрий Пилевич \\ ТРАНСФОРМАЦИЯ СИСТЕМЫ БУХГАЛТЕРСКОГО УЧЕТА \\ В УСЛОВИЯХ РАЗВИТИЯ ЦИФРОВЫХ ТЕХНОЛОГИЙ
}

\author{
Dmytro Pilevych \\ TRANSFORMATION OF THE ACCOUNTING SYSTEM \\ IN THE CONDITIONS OF DIGITAL TECHNOLOGIES DEVELOPMENT
}

Мета статті полягає в обтрунтуванні основних напрямів трансформацї системи бухгалтерського обліку в умовах розвитку ичиррових технологій. У статті обтрунтовано, щцо иифррові технології є пріоритетом у розвитку бухгалтерського обліку, спроможним радикально трансформувати принципи його функціонування. Систематизовано ключові переваги впровадження ијифрових технологій: оптимізачія та економія витрат підприємства; розширення доступу стейкхолдерів до фінансової інформачії; забезпечення вищої ивидкості роботи з обліковою інформаијією в режимі реального часу; транспарентність операцій; зростання рівня довіри з боку клієнтів; простий $i$ зрозумілий інтерфейс та збільшення обсягів збереження облікових, податкових звітних даних. Відзначено, що некоректне чи непрофесійне використання ијиррових технологій зумовлює виникнення ризиків: похибки при побудові алгоритмів; прорахунки в ріменнях щодо масштабів впровадження таких технологій; втрата даних, порушення їхньої иілісності; зниження рівня захисту й конфіденційності інформації, операцій; технічні збої; кібератаки.

Ключові слова: бухгалтерський облік; ичирові технології; автоматизація; итучний інтелект; хмарні технологіï; блокчейн; Big Data.

Рис.: 2. Бібл.: 16

Цель статьи состоит в обосновании основных направлений трансформации системы бухгалтерского учета в условиях развития ичирровых технологий. В статье обосновано, что иифровые технологии являются приоритетом в развитии бухгалтерского учета, способным радикально трансформировать принципы его функционирования. Систематизированы ключевые преимущества внедрения иифровых технологий: оптимизация и экономия расходов предприятия; расширение доступа стейкхолдеров к финансовой информачии; обеспечения высокой скорости работы с учетной информацией в режиме реального времени; транспарентность операций; рост уровня доверия со стороны клиентов; простой и понятный интерфейс и увеличение объемов хранения учетных, налоговых отчетных данных. Автором отмечено, что некорректное или непрофессиональное использование цифровых технологий обусловливает возникновение рисков: ошибки при построении алгоритмов; просчеты в решениях относительно масштабов внедрения таких технологий; потеря данных, нарушения их иелостности; снижение уровня защиты и конфиденциальности информачии, операџий; технические сбои; кибератаки.

Ключевые слова: бухгалтерский учет; ичифровые технологии; автоматизация; искусственный интеллект; облачные технологии; блокчейн; Big Data.

Рис.: 2. Библ.: 16.

The purpose of the article is to substantiate the main directions of transformation of the accounting system in the conditions of digital technologies development. The article substantiates that digital technologies are a priority vector of the accounting development; the digital technologies are able to radically transform the principles of functioning of the accounting system. The key advantages of introduction of digital technologies are identified, namely: optimization and economy of expenses of the enterprise; expanding access of stakeholders to financial information; ensuring higher speed of work with accounting information in real time; transparency of operations; increasing the level of trust from customers; simple and clear interface, and increase in storage of accounting, and tax reporting data. The author notes that incorrect or unprofessional use of digital technologies causes risks: errors in the construction of algorithms; miscalculations in decisions on the scale of implementation of digital technologies; data loss; violation of integrity of information; reducing the level of protection and confidentiality of information; technical failures; cyber attacks.

Keywords: accounting; digital technologies; automatizaton; Artificial Intelligence; cloud technologies; blockchain; Big Data.

Fig.: 2. References: 16

JEL Classification: M41; D83

Постановка проблеми. Функціонування підприємств відбувається в турбулентних умовах динамічного екзогенного середовища. Цифровізація національної економіки висуває низку нових викликів до сучасного бізнесу. Спроможність підприємства оперативно й адекватно реагувати на ці виклики визначає рівень його конкурентоспроможності на ринку. Своєчасне прийняття управлінських рішень у контексті диджиталізації потребує високої кваліфікації персоналу та технічної спроможності підприємства акумулюва-

() Пілевич Д. С., 2020 
ти, обробляти, аналізувати, оформлювати, зберігати та передавати інформацію стейкхолдерам. Особлива ж увага має бути приділена організації ефективної роботи 3 обліково-аналітичними даними, що формують базу прийняття виважених рішень на різних рівнях управління. Окреслене можливе виключно за умови широкого впровадження новітніх інформаційних технологій у систему бухгалтерського обліку підприємства. Це створить передумови для забезпечення оперативності проведення операцій, повноти й точності інформації, а також для зниження трудомісткості процесу обробки обліковоаналітичних даних.

У контексті стрімкого розвитку науки, техніки і технологій трансформуються інструменти й технології обліку на оподаткування. Відповідно, актуалізується необхідність перманентного моніторингу змін інформаційних технологій та інтенсивності їхнього впливу на систему бухгалтерського обліку.

Аналіз останніх досліджень і публікацій. Проблема застосування інформаційних технологій у бухгалтерському обліку піднімається в наукових працях таких українських учених, як І. Спільник, М. Палюх, О. Шапаренко. Різноманітні аспекти використання цифрових технологій бухгалтерами й аудиторами порушують у публікаціях А. Гаврилюк, Н. Голячук, М. Прохоров, О. Мельниченко.

Актуальність порушеної в цій статті проблеми зумовлює появу низки наукових публікацій, присвячених аналізу специфіки впливу конкретних технологій на розвиток бухгалтерського обліку та аудиту. Зокрема, технологій машинного навчання, аналізу великих даних, хмарних технологій, блокчейну, штучного інтелекту тощо (Н. Рогова, В. Мінакова, К. Шіковець, В. Фролов, С. Король, А. Клочко, Т. Соколова, І. Волошин, І. Петрушин та ін.).

Виділення недосліджених частин загальної проблеми. Високо оцінюючи наявні наукові напрацювання щодо розвитку системи бухгалтерського обліку й аудиту, все ж маємо відзначити, що недостатньо дослідженою залишається проблема визначення теоретико-прикладних засад трансформації такої системи в сучасних умовах інтенсивного впровадження інформаційних технологій.

Мета статті полягає в обгрунтуванні основних напрямів трансформації системи бухгалтерського обліку в умовах розвитку цифрових технологій.

Виклад основного матеріалу. Автоматизація системи бухгалтерського обліку на поточному етапі його розвитку відбувається під потужним впливом інформаційних технологій. Апробовані напрями автоматизації облікових процесів на підприємстві систематизовано на рис. 1.

Перевірені на практиці інформаційні системи бухгалтерського обліку (тоді як «1С: Підприємство», «ДЕБЕТ Плюс», «MASTER: Бухгалтерія» тощо) відрізняються чітким дотриманням регламенту, дисципліни процесів та строгою формалізацією [1; 11]. Перевагами автоматизації є забезпечення високої оперативності прийняття управлінських рішень, підвищення ефективності управління персоналом, оптимізація контролю на підприємстві (зокрема, над дебіторською заборгованістю), а також зростання ефективності діяльності підприємства загалом [12].

Поряд із цим, застосування сучасних інформаційних технологій у системі бухгалтерського обліку не вирішує проблем верифікації даних, забезпечення їх повноти, точності й актуальності. Окремо варто наголосити на загостренні проблеми гарантування безпечності інформації від третіх осіб. Нині для вирішення зазначених проблемних моментів розроблено низку інструментів і технік, проте жодна з них не дає бажаного результату або виявляється недостатньо надійною у довгостроковому періоді. Відповідно, при роботі із сучасними технологіями необхідно на перманентній основі здійснювати моніторинг їх зміни та відстежувати технологічні інновації в системі бухгалтерського обліку. Це забезпечить підприємству не лише спроможність бути конкурентним на ринку і йти в ногу з часом, а й дозволить мінімізувати ризики хакерських атак, втрати інформації, частини доходу чи репутації. 
ФІНАНСОВІ РЕСУРСИ: ПРОБЛЕМИ ФОРМУВАННЯ ТА ВИКОРИСТАННЯ

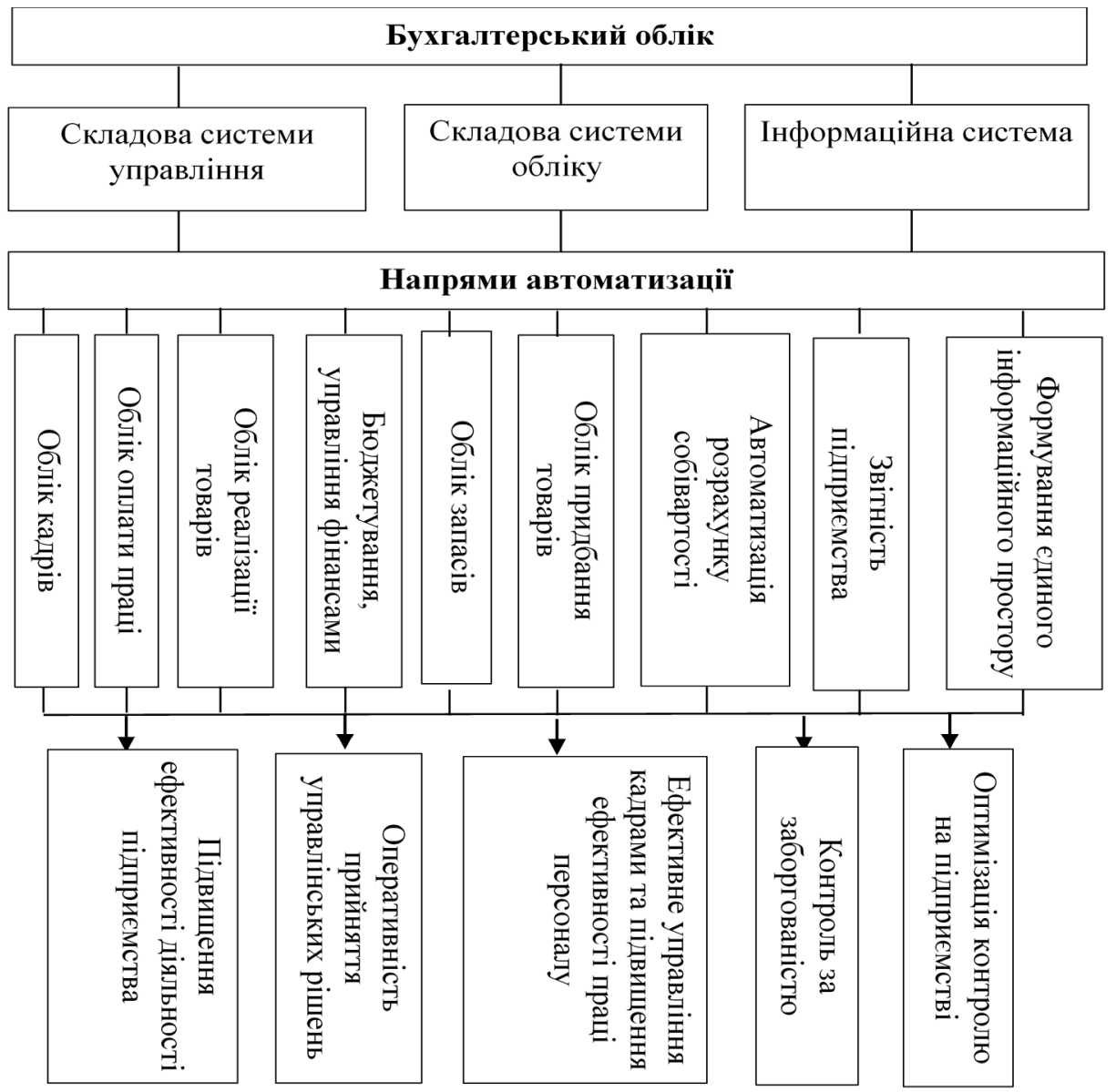

Рис. 1. Ключові напрями автоматизачиї облікових прочесів

Джерело: побудовано автором на основі $[6 ; 12 ; 16]$.

У межах цієї статті ми ставимо перед собою мету проаналізувати вплив сучасних цифрових технологій на розвиток бухгалтерського обліку. Більшість науковців і експертів вбачає суттєві перспективи для розвитку системи обліку на підприємстві в технологіях штучного інтелекту, машинного навчання, хмарних обчислень. Розглянемо детальніше імовірні ефекти від їх впровадження в діяльність господарюючих суб' єктів.

Штучний інтелект являє собою інтелектуальну комп'ютерну систему, наділену можливостями розпізнавання мови, навчання та вирішення проблем. Іншими словами, цю цифрову технологію можна віднести до групи інноваційних і визначити як «комплекс споріднених технологій і процесів» [9], спроможних до оперативної обробки, аналізу, акумулювання та збереження великих масивів інформаційних ресурсів.

Технології штучного інтелекту й машинного навчання можуть бути успішно застосовані для автоматизації регулярно повторюваних та структурованих завдань. Пріоритетні напрями: управління дебіторською і кредиторською заборгованістю, кодування облікових записів, управління витратами, управління грошовими потоками. Використання зазначених цифрових технологій дасть змогу не лише автоматизувати, а й підвищити ефективність процесів формування звітів, інвентаризації, аудиту, сплати податку на додану вартість [11].

Крім цього, штучний інтелект та машинне навчання $є$ технологіями, цілком застосовними і для вирішення нестандартних та неструктурованих завдань. До прикладу, таких задач, як побудова прогностичних моделей (зокрема, при прогнозуванні доходів та грошових потоків), управління закупівлями, удосконалення доступу до неструктурованих даних, а також виявлення шахрайських схем [11]. 
Визначаючи переваги впровадження технологій штучного інтелекту в систему бухгалтерського обліку на підприємстві, важливо наголосити на імовірності виникнення при цьому низки викликів. Зокрема, до них можна віднести кібератаки, програмні помилки, похибки в алгоритмах. Також треба враховувати факт низької правової врегульованості питань застосування сучасних цифрових технологій обліку, що провокує виникнення правових колізій при використанні штучного інтелекту [11]. Проте існування ризиків неспроможне нівелювати позитивні ефекти від імплементації технологічних інновацій.

Хмарні технології (Cloud computing) являють собою сукупність технологій, що $€$ пов'язаними між собою, становлять єдиний комплекс обробки даних і передбачають постійне збереження інформації на серверах у мережі Інтернет із іiї кешуванням на ПК чи гаджетах (клієнтський бік). Взагалі це цифрова технологія, в якій потужності та ресурси надаються як інтернет-сервіс [2;9].

Технології хмарних обчислень здійснюються у процесі реалізації заходів із підвищення рівня безпеки інформації, резервного іiі копіювання, контролю, розширення доступу до неї і масштабування. Такі технології надають можливість доступу до інформації в режимі реального часу, гарантують цілісність і безпечність даних завдяки процедурам шифрування та багатофакторний аутентифікації. Специфіка хмарних обчислень дозволяє значно економити на витратах часу, капітальних та експлуатаційних витратах на ITінфраструктуру [11]. Схематично напрями використання хмарних обчислень у системі бухгалтерського обліку та відповідні позитивні ефекти представлено на рис. 2. Варто зазначити тренд до розширення ринку онлайн-бухгалтерії на основі цієї технології (FreshBooks, Xero, Myob, Liquid, QuickBooks online тощо), зокрема лідерами на ньому виступають компанії SAD, KPMG, Ernst\&Young. Також простежується тенденція до зростання пропозиції програм бухгалтерського обліку на віртуальних сервісах (Tuch.ua; «1C: Зарплата і управління персоналом»). Відповідні продукти не передбачають придбання спеціалізованих дороговартісних програм, сервера чи розширення штату бухгалтерів і є достатньо бюджетними [11].

Аналізуючи трасформуючий вплив інноваційних інформаційних технологій на систему бухгалтерського обліку, необхідно виокремити так звані «великі дані» (Big Data). Ця технологія може застосовуватись в управлінському обліку, звітності, управлінні ризиками, аналізі договорів. За своєю суттю, Big Data $€$ сукупністю методів та інструментів обробки величезних масивів інформації, що можуть ефективно використовуватись в умовах безперервного і стрімкого приросту обсягів структурованих та неструктурованих даних із різних джерел [8; 9].

Наступна інформаційна технологія, що активно застосовується для ведення бухгалтерських записів-блокчейн (blockchain). Це цифровий регістр, база даних, де транзакції зберігаються у структурованих блоках, а інформація про них фіксується у хронологічній послідовності та $є$ відкритою для всіх користувачів бази. У технології blockchain передбачається, що блоки $є$ тісно пов'язаними один з одним, містять інформацію про транзакції, записані в попередніх блоках $[7 ; 9 ; 10 ; 13]$. Головними перевагами такої технології є прозорість, надійність і спроможність працювати, аналізувати та перевіряти облікову інформацію в режимі реального часу. Варто відзначити, що сучасні інформаційні технології широко використовуються в системі оподаткування. Станом на сьогодні вже впровадженими в діяльність фіскальної служби є електронні підходи і сервіси по роботі з платниками податків (кабінет платника податків, система автоматичного відшкодування ПДВ, електронний чек, акциз та аудит). Нині триває активна робота з розробки спеціальних мобільних додатків для автоматизації процесів взаємодії фіскальної служби із суб'єктами господарювання [11]. 
ФІНАНСОВІ РЕСУРСИ: ПРОБЛЕМИ ФОРМУВАННЯ ТА ВИКОРИСТАННЯ

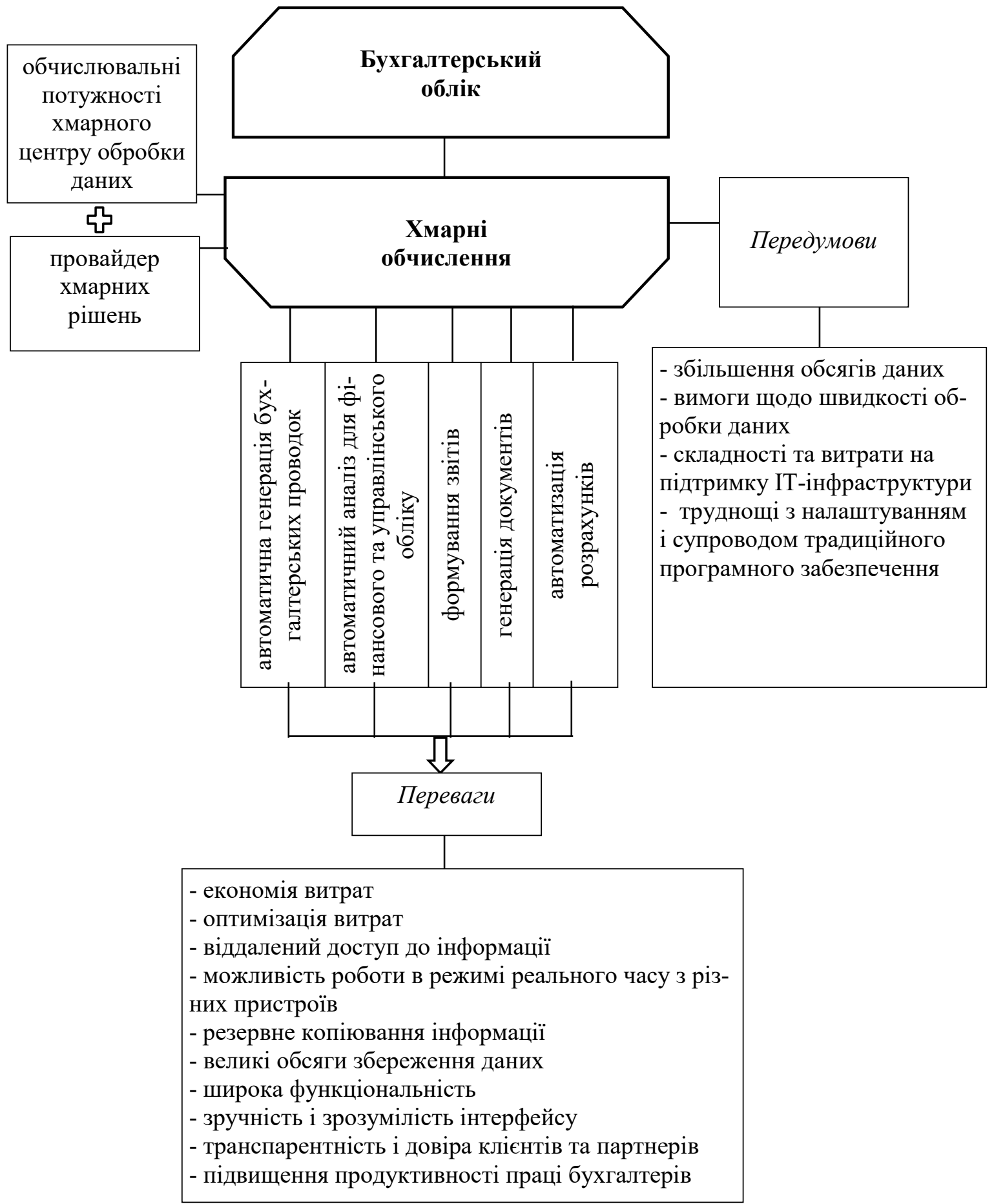

Рис. 2. Ефекти від використання хмарних технологій у системі бухгалтерського обліку Джерело: побудовано автором на основі $[11 ; 14 ; 15]$.

Електронні сервіси дозволяють спростити та зробити більш комфортним процес сплати податків фізичним особам. Такі сервіси забезпечують онлайн-доступ користувачів до даних, підтримують функціонування аналітичних сервісів, дають змогу вести зручну комунікацію i, що особливо важливо, - формувати та подавати звітність. Автоматизація в податковій системі створює можливості для проведення операцій платниками податків у будьякий час доби, а не обмежуватись робочими та приймальними годинами працівників фіскальних служб, підлаштовувати власний графік під режим їхньої роботи. 
3 іншого боку, для ревізорів і аудиторів автоматизація системи також несе низку переваг, оскільки супроводжується веденням реєстрів платників податків та здійсненням електронного аудиту, дає змогу акумулювати величезні обсяги податкових даних. Завдяки формуванню робочих планів ревізорів, автоматизованому відбору ризикових операцій і суб'єктів вдається скоротити витрати часу, збільшити обсяги надходжень податків до бюджету [11]. Важливо зазначити, що саме автоматизація систем бухгалтерського обліку й оподаткування становить основу боротьби з корупцією в країні.

Штучний інтелект застосовується для реалізації управлінської та контрольної функції фіскальної служби. Зокрема, до звичних і апробованих методів фінансової аналітики додаються прогнозні поведінкові моделі. Це дозволяє на основі податкової та платіжної дисципліни виявити імовірні ризики чи проблеми, пов'язані з не доброчесністю у сплаті податків у майбутніх періодах, а відповідно, своєчасно вжити превентивні заходи. Отримані таким чином дані використовуються при вибудовуванні стратегії взаємодії фіскальних органів із платниками податків [11].

Технології штучного інтелекту та машинного навчання застосовними для групування платників податків за параметрами їхньої податкової дисципліни та для виявлення способів уникнення сплати податків і податкових зборів. Зазначена інформація використовується при застосуванні персоніфікованого підходу у ході вдосконалення політики оподаткування. Крім окресленого вище, сучасні цифрові технології дозволяють здійснювати скоринг платників податків, планувати й організовувати податкові перевірки [11].

У науковій літературі обгрунтовуються вагомі перспективи технологій штучного інтелекту в автоматизації процесів обробки аудиторської та фінансової звітності [4]. Такі висновки грунтуються значною мірою на позитивному світовому досвіді. Зокрема, в Іспанії віртуальні помічники задіюються для опрацювання запитів, аналізу податкових ризиків, попереднього заповнення декларацій з ПДВ і надання відповідної інформації в режимі реального часу. Тобто переважно такі технології застосовуються в консультаційній і просвітницькій діяльності податкової агенції [11].

Незважаючи на сферу застосування, ефективне впровадження цифрових технологій передбачає модернізацію IT-інфраструктури, налагодження співпраці 3 FinTechкомпаніями, залучення нового покоління фахівців, обізнаних зі специфікою бухгалтерського обліку й аудиту та з особливостями прогнозної аналітики, моделювання.

Активне впровадження інформаційних технологій (хмарних обчислень, штучного інтелекту, великі дані, блокчейн тощо) в систему бухгалтерського обліку позначається не лише на принципах його реалізації, а і на професії бухгалтера. До базових компетентностей зі знання державних і міжнародних стандартів фінансової звітності, законодавчих норм та нормативів даються вимоги щодо володіння бухгалтерами спеціалізованим програмним забезпеченням, обізнаності зі спеціальними IT-рішеннями. Сучасний бухгалтер повинен володіти компетентностями комунікації зі стейкхолдерами в умовах віртуального співробітництва; формування корпоративної звітності, що потребує знань із фінансової математики та навичок роботи із програмним забезпеченням для аналізу, інтерпретації, подання інформації; уміння працювати з інструментами аналізу даних та експертних систем. Крім цього, висуваються вимоги щодо soft skills бухгалтерів, а саме їхньої спроможності налагоджувати ефективну міжкультурну взаємодію, володіння іноземною мовою, критичне мислення, кросфункціональність, адаптивність до інновацій, уміння виявляти ризики та пріоритезувати завдання [9].

Серед ключових пріоритетних напрямів впровадження сучасних цифрових технологій виокремлюють облік і оподаткування операцій із криптовалютами. Станом на 2020 р. в Україні досі не визначено правовий статус криптовалют [3; 5]. 3 одного боку, це пов'язано з недостатньою вивченістю крипто валют, а з іншого боку, браком досвіду 
ФІНАНСОВІ РЕСУРСИ: ПРОБЛЕМИ ФОРМУВАННЯ ТА ВИКОРИСТАННЯ

країн світу й відсутністю дієвих практик регулювання процесів обігу криптовалюти, апробованих механізмів їх оподаткування. Уряди переважно орієнтуються на рекомендації міжнародних організацій та займають позицію спостерігача.

Процеси обліку криптовалюти є ускладненими з огляду на їх широке розмаїття, відсутність єдиного підходу до їх класифікації як об'єкта обліку, властиві їм специфічні особливості. Якщо позиціонувати криптовалюти як активи, то обліковувати їх можуть як готівку, як не грошові фінансові активи, як інвестиційну нерухомість, як нематеріальні активи, як запаси [11].

Аналогічно труднощі на практиці виникають при оподаткуванні операцій із критовалютами. Оскільки у правовому полі криптовалюти чітко не визначені, то вони перебувають поза межами податкового регулювання в низці країн світу. Водночас певний досвід у цій сфері вже має Японія (оподаткування прибутку від продажу й обміну криптовалюти), Сінгапур (прибутку від продажу, майнінгу), Ізраїль (доходів від капіталу), Сполучені Штати Америки і Мальта (прибутку), Швейцарія (прибутку, приросту капіталу) [11].

При проведенні обліку операцій з криптовалютою в Україні необхідно, по-перше, грунтовно проаналізувати провідний світовий досвід; по-друге, чітко визначити правовий статус криптовалюти; по-третє, врахувати особливості національної економіки, і бухгалтерської та податкової системи в країні зокрема.

Висновки та пропозиції. Цифрові технології (як штучного інтелекту, так і хмарних обчислень тощо) є однозначним пріоритетом у розвитку бухгалтерського обліку, спроможним радикально трансформувати принципи його практичної реалізації, переводячи його при цьому на якісно новий рівень функціонування, комунікації зі стейкхолдерами i прийняття управлінських рішень. Ключовими перевагами впровадження таких технологій $є$ оптимізація та економія витрат підприємства, розширення доступу стейкхолдерів до фінансової інформації, забезпечення вищої швидкості роботи з обліковою інформацією в режимі реального часу, транспарентність операцій, зростання рівня довіри з боку клієнтів, а також простий і зрозумілий інтерфейс та збільшення обсягів збереження облікових, податкових звітних даних.

Некоректне чи непрофесійне використання цифрових технологій обумовлює виникнення таких ризиків: похибки при побудові алгоритмів; прорахунки в рішеннях щодо масштабів впровадження таких технологій; втрата даних, порушення їх цілісності; зниження рівня захисту й конфіденційності інформації, операцій; технічні збої тощо. Поряд із цим, у зв'язку з наявними ризиками (кібератаки, втрати інформації, пошкодження цілісності даних тощо) новітні цифрові технології у практику діяльності українських підприємств впроваджуються порівняно повільним темпами. 3 огляду на це перспективами подальших наукових досліджень $є$ пошук ефективних інструментів і методів аналізу й мінімізації ризиків, проведення IT-аудиту, страхування ризиків, пов'язаних із цифровізацією бухгалтерського обліку.

\section{Список використаних джерел}

1. Гаврилюк А. Яку 1С вибрати: в хмарі чи локальну? / Проект «Голос Сокальщини». 2019. URL: https://golossokal.com.ua/cikavo/yaku-1 s-vybraty-v-khmari-chy-lokal-nu.html.

2. Голячук Н. В., Голячук С. Є. Переваги та недоліки застосування хмарних технологій в обліку. Економічні науки. Серія: Облік і фінанси. 2015. Вип. 12(1). С. 80-86.

3. Дубина М. В., Холявко Н. І., Моротченко І. Ю. Криптовалюти: сутність та етапи еволюції. Фінансові дослідження : електронний науковий журнал. 2019. № 1 (6). URL: https://fr.stu.cn.ua/ index.pl?task $=$ arcinf $\& l=u a \& j=19 \& i d=178$.

4. Дубина М. В. Механізм розвитку ринку фінансових послуг на основі інституту довіри: теорія, методологія, практика : монографія. Чернігів : ЧНТУ, 2018. 668 с.

5. Дубина М. В., Жаворонок А. В., Федишин М. П. Формування інституційного середовища розвитку криптовалют в Україні. Modern Economics. 2019. Vol. 17. Pp. 80-85. 
6. Король С. Я., Клочко А. О. Цифрові технології в обліку і аудиті. Держава та регіони. Серія: Економіка та підприємництво. 2020. Вип. 1 (112). C. 170-176. URL: http://www.econom.stateandregions.zp.ua/journal/2020/1_2020/31.pdf.

7. Мельниченко О. В., Гартінгер Р. О. Роль технології блокчейн у розвитку бухгалтерського обліку та аудиту. European Cooperation. 2016. № 7 (14). С. 9-19.

8. Мінакова В. П., Шіковець К. О. Актуальність використання моделі Big Data в бізнеспроцесах. Економіка і суспільство. 2017. № 10. С. 892-896.

9. Плікус І., Жукова Т., Осадча О. Модель професії бухгалтер в епоху цифрових трансформацій: ключові напрями компетентностей бухгалтера. Приазовський економічний вісник. 2019. Вип. 1 (12). С. 200-205.

10. Прохоров М. В. Як блокчейн змінить бухгалтерію. Бухгалтер \& Закон. 2019. № 47-48. URL: http://bz.ligazakon.ua/magazine_article/BZ012012.

11. Рогова Н. Трансформація політики, інструментів і технологій обліку та оподаткування в умовах цифрової економіки. Фінансовий простір. 2020. № 2 (38). С. 103-116.

12. Скриньковський Р., Гладун В., Крамар М. (2019) Інформаційні технології в організації бухгалтерського обліку на підприємстві. Traektoriâ Nauki = Path of Science. Vol. 5. No 2. Pp. 3001-3010.

13. Соколова Т. Н., Волошин И. П., Петрунин И. А. Преимущества и недостатки технологии блокчейн. Экономическая безопасность и качество. 2019. № 1(34). С. 49-52.

14. Спільник I. В., Палюх М. С. Бухгалтерський облік в умовах цифрової економіки. Інститут бухгалтерського обліку, контроль та аналіз в умовах глобалізаџіï. 2019. Вип. 1-2. С. 83-96.

15. Фролов В. І. Впровадження «хмарних» технологій в практику бухгалтерського обліку. Бухгалтерський облік і аудит. 2013. № 12. С. 45-49.

16. Шапаренко О. В. Вплив інформаційних технологій на бухгалтерський облік. Зовнішня торгівля: економіка, фінанси, право. 2014. № 2. С. 129-134.

\section{References}

1. Havryliuk, A. (2019). Yaku IS vybraty: v khmari chy lokalnu? [Which 1C to choose: in the cloud or local?]. https://golossokal.com.ua/cikavo/yaku-1s-vybraty-v-khmari-chy-lokal-nu.html.

2. Holiachuk, N. V., Holiachuk, S. Ie.(2015). Perevahy ta nedoliky zastosuvannia khmarnykh tekhnolohii $\mathrm{v}$ obliku [Advantages and disadvantages of using cloud technologies in accounting]. Ekonomichni nauky. Seriia: Oblik i finansy - Economic sciences. Series: Accounting and Finance, 12(1), pp. 80-86.

3. Dubyna, M. V., Kholiavko, N. I., Morotchenko, I. Yu. (2019). Kryptovaliuty: sutnist ta etapy evoliutsii [Cryptocurrencies: the essence and stages of evolution]. Finansovi doslidzhennia Financial researcher, 1 (6). https://fr.stu.cn.ua/index.pl?task=arcinf\&l=ua\&j=19\&id=178.

4. Dubyna, M. V. (2018). Mekhanizm rozvytku rynku finansovykh posluh na osnovi instytutu doviry: teoriia, metodolohiia, praktyka [The mechanism of development of the market of financial services on the basis of the institute of trust: theory, methodology, practice]. ChNTU.

5. Dubyna, M. V., Zhavoronok, A. V., Fedyshyn, M. P. (2019). Formuvannia instytutsiinoho seredovyshcha rozvytku kryptovaliut v Ukraini. Modern Economics, 17, 80-85.

6. Korol, S. Ia., Klochko, A. O. (2020). Tsyfrovi tekhnolohii v obliku i audyti [Digital technologies in accounting and auditin] Derzhava ta rehiony. Seriia: Ekonomika ta pidpryiemnytstvo - State and regions. Series: Economics and Entrepreneurship, 1(112), pp. 170-176. http://www.econom.stateandregions.zp.ua/journal/2020/1_2020/31.pdf.

7. Melnychenko, O. V., Hartinher, R. O. (2016). Rol tekhnolohii blokchein u rozvytku bukhhalterskoho obliku ta audytu [The role of blockchain technology in the development of accounting and auditing]. European Cooperation, 7 (14), pp. 9-19.

8. Minakova, V. P., Shikovets, K. O. (2017). Aktualnist vykorystannia modeli Big Data v biznesprotsesakh [The relevance of using the Big Data model in business processes] Ekonomika i suspilstvo - Economy and society, 10, pp. 892-896.

9. Plikus, I., Zhukova, T., Osadcha, O. (2019). Model profesii bukhhalter v epokhu tsyfrovykh transformatsii: kliuchovi napriamy kompetentnostei bukhhaltera [Model of the profession of accountant in the era of digital transformations: key areas of competence of the accountant] Pryazovskyi ekonomichnyi visnyk - Priazovsky Economic Bulletin, 1 (12), pp. 200-205. 
ФІНАНСОВІ РЕСУРСИ: ПРОБЛЕМИ ФОРМУВАННЯ ТА ВИКОРИСТАННЯ

10. Prokhorov, M. V. (2019). Yak blokchein zminyt bukhhalteriiu [How the blockchain will change accounting]. Bukhhalter \& Zakon - Accountant \& Law, 47-48. http://bz.ligazakon.ua/ magazine article/BZ012012.

11. Rohova, N. (2020). Transformatsiia polityky, instrumentiv i tekhnolohii obliku ta opodatkuvannia $\mathrm{v}$ umovakh tsyfrovoi ekonomiky [Transformation of policies, tools and technologies of accounting and taxation in a digital economy]. Finansovyi prostir - Financial area, 2 (38), pp. $103-116$.

12. Skrynkovskyi, R., Hladun, V., Kramar, M. (2019). Informatsiini tekhnolohii v orhanizatsii bukhhalterskoho obliku na pidpryiemstvi [Information technology in the organization of accounting at the enterprise]. Traektoriâ Nauki = Path of Science, 5(2), pp. 3001-3010.

13. Sokolova, T. N., Voloshyn, Y. P., Petrunyn, Y. A. (2019). Preymushchestva y nedostatky tekhnolohyy blokchein [Advantages and disadvantages of blockchain technology]. Ekonomycheskaia bezopasnost y kachestvo - Economic security and quality, (34), pp. 49-52.

14. Spilnyk, I. V., Paliukh, M.S. (2019). Bukhhalterskyi oblik v umovakh tsyfrovoi ekonomiky [Accounting in the digital economy]. Instytut bukhhalterskoho obliku, kontrol ta analiz $v$ umovakh hlobalizatsii - Institute of Accounting, Control and Analysis in the context of globalization, 1-2, pp. 83-96.

15. Frolov, V.I. (2013). Vprovadzhennia «khmarnykh» tekhnolohii v praktyku bukhhalterskoho obliku [Introduction of "cloud" technologies in the practice of accounting]. Bukhhalterskyi oblik $i$ audit-Accounting and auditing, 12, pp. 45-49.

16. Shaparenko, O. V. (2014). Vplyv informatsiinykh tekhnolohii na bukhhalterskyi oblik [The impact of information technology on accounting] Zovnishnia torhivlia: ekonomika, finansy, parvo Foreign trade: economics, finance, law, 2, pp. 129-134.

|Пілевич Дмитро Станіславович - кандидат економічних наук, Університет ДФС України (вул. Університетська, 31, м. Ірпінь, 08201. Україна).

Пилевич Дмитрий Станиславович - кандидат экономических наук, Университет ДФС Украины (ул. Университетская, 31, г. Ирпень, 08201, Украина).

Pilevych Dmytro - PhD in Economics, University of DFS of Ukraine (31 Universytetska Str., 08201 Irpin, Ukraine).

E-mail: dmutrostan@ukr.net

ORCID: https://orcid.org/0000-0002-9442-0262

Пілевич Д. Трансформація системи бухгалтерського обліку в умовах розвитку цифрових технологій. Проблеми $і$ перспективи економіки та управління. 2020. № 3(23). С. 149-157. 